\title{
DOES GERONTOPSYCHIATRY BELONG TO MEDICINE? CROSS-SECTIONAL STUDY MONITORING POLYMORBIDITY IN HOSPITALIZED GERONTOPSYCHIATRIC PATIENTS
}

\author{
Jan Luzny,a*, Jana Bellova ${ }^{\mathrm{b}}$, Emanuel Donek ${ }^{\mathrm{a}}$
}

\author{
${ }^{a}$ Psychiatric Hospital Kromeriz, Czech Republic \\ ${ }^{b}$ Department of Social Medicine and Health Policy, Faculty of Medicine and Dentistry, Palacky University, Olomouc, Czech \\ Republic \\ E-mail:luznyj@plkm.cz
}

Received: August 31, 2009; Accepted: February 4, 2010

Key words: Gerontopsychiatry/Polymorbidity/Polypharmacy

Background. A cross-sectional study has been designed and the study observes the prevalence of polymorbidity in senior inpatients suffering from psychiatric morbidity hospitalized in gerontopsychiatric ward in one of the biggest psychiatric hospitals in the Czech Republic. The aim of the study is to prove that gerontopsychiatry is a comprehensive specialization for both doctors and nurses and should not be viewed as a low-status medical specialization.

Methods and results. A cross-sectional study comprising of 304 patients was designed and a simple descriptive analysis of the patients' medical records was carried out. Polymorbidity and serious somatic conditions were present in senior patients hospitalized in gerontopsychiatric ward. Polypharmacy is a widespread phenomenon and has hazardous side effects for the treatment of patients. Last but not the least it also makes the treatment more expensive.

Conclusion. Both doctors and nurses working in gerontopsychiatry should have a comprehensive interdisciplinary knowledge that would help in both early detection of many serious somatic conditions and in the improvement of the reputation of gerontopsychiatry.

\section{INTRODUCTION}

The laymen population of the Czech Republic tends to disregard Gerontopsychiatry. This sub specialization of psychiatry suffers from inadequate financial support, surprisingly the same situation as in the Czech Republic is sometimes seen in other parts of the world ${ }^{1}$. Concept of gerontopsychiatry in world is undergoing new modifications respecting new challenges of society and the needs of modern society ${ }^{2-3}$.

In the Czech Republic many seniors with psychiatric morbidity are hospitalized in traditional institutions, such as psychiatric hospitals, geriatric hospitals or general hospitals. These institutions maintain very often rigid and stereotypical management of therapy, non complying with the holistic approach and biopsychosociospiritual concept of patients' needs ${ }^{4}$. Many senior citizens - especially those with psychiatric morbidity such as severe dementia - were allocated in psychiatric hospitals by their own families which simply refuse taking care of them ${ }^{5}$.

Hence, the burden put on gerontopsychiatry increases. Gerontopsychiatrists and nurses come across patients with both psychiatric diseases (like dementia, delirious states or affective disorders) and somatic diseases as well. They are entirely responsible for the management of treatment of both psychiatric and somatic conditions. Therefore knowledge of all parts of medicine is needed. A typical patient hospitalized in gerontopsychiatric ward is suffering from somatic polymorbidity, including noncommunicable diseases, and polypharmacy (Table 1).
Somatic polymorbidity means the presence of two or more diseases in an individual at the same time. In geriatrics and gerontopsychiatry clusters of both somatic and psychiatric diseases are a typical characteristic feature ${ }^{6,7}$.

Non-communicable diseases represent a shift in morbidity in the $21^{\text {st }}$ century compared to the morbidity of former centuries. While infectious diseases were threatening conditions in $19^{\text {th }}$ century and the beginning of the $20^{\text {th }}$ century (tuberculosis, poliomyelitis, wound infection, puerperal sepsis), the $21^{\text {th }}$ century brings pandemia of new diseases such as obesity, hypertension, diabetes mellitus or musculoskeletal diseases. Non-communicable diseases (NCD's) have both economical and ethical aspects ${ }^{8}$.

Polypharmacy represents an administration of more medication than is in fact needed, or administration of drugs in unsuitable combination. Usually it means admin-

Table 1. What makes treatment of diseases in senior age difficult?

\begin{tabular}{|l|}
\hline What makes treatment of diseases in senior age difficult? \\
\hline - Somatic and psychiatric polymorbidity \\
\hline - Presence of non-communicable diseases \\
\hline - Polymorbidity - risk of side / adverse effects \\
\hline - Changes in pharmacokinetics \\
\hline - Changes in pharmacodynamics \\
\hline
\end{tabular}


istration of more than 4 drugs at the same time. The risk of polypharmacy increases with the age of patients and polymorbidity $6,7,9,11$. Polypharmacy also increases total expenditures spent on health care ${ }^{12}$.

Diseases of senior citizens usually have a modified clinical picture, accompanied by microsymptomatology (the symptoms of diseases are less expressed than in the general population, for instance, in bacterial infections fever or leukocytosis can be missing ), monosymptomatology or oligosymptomatology (symptoms of diseases can be expressed only by one or several symptoms instead of typical syndromology, for instance thyreotoxicosis can be revealed only by atrial tachyfibrilation or weight loss without the other typical symptoms), non-specific clinical signs (such as anorexia, fatigue, malaise, which can be observed in many different conditions), symptoms of secondary deterioration (first clinical signs of a disease comes from the organ with the worst adaptation and the worst functional status, for instance delirious states as cerebral dysfunction caused primarily by bacterial infection), cascades of clinical signs (clinical signs coming from deterioration of more organs - „domino effect“ of primary pathological condition ), atypical adverse effects of therapy (due to changes in pharmacodynamics and pharmacokinetics of used drugs), risk of acute or emergent deterioration of performance status because of disease, high potential of invalidity caused by a disease (loss of autonomy, loss of independence in activities of daily living), social impact of a disease (risk of hospitalization and institutionalization) (Table 2$)^{7,10}$.

Table 2. Features of morbidity in senior age.

\begin{tabular}{|l|}
\hline \multicolumn{1}{|c|}{ Features of morbidity in senior age } \\
\hline - Microsymptomatology \\
\hline - Monosymptomatology or oligosymptomatology \\
\hline - Non-specific clinical signs \\
\hline - Symptoms of secondary deterioration \\
\hline - Cascades of clinical signs \\
\hline - Atypical adverse effects of therapy \\
\hline - Risk of acute or emergent deterioration of perfor- \\
mance status because of disease \\
\hline - High potential of invalidity caused by a disease \\
\hline - Social impact of a disease \\
\hline
\end{tabular}

Translated and modified according to Topinkova et al. ${ }^{7}$

\section{METHODS}

A cross-sectional study of 8 gerontopsychiatric wards located in the Psychiatric hospital Kromeriz which is one of the biggest psychiatric hospitals in the Czech Republic was carried out. The study consisted of 304 patients (101 men, 203 women) hospitalized in gerontopsychiatric wards from February 2009 to June 2009. A descriptive analysis of medical records and patients' anamneses was carried out. Patients were not exposed to any ethical issues. The Helsinki declaration on research was respected.

\section{RESULTS}

\begin{tabular}{|l|c|}
\hline \multicolumn{2}{|c|}{ Characteristic of group } \\
\hline Number of patients & 304 \\
\hline Age of group & $\begin{array}{c}71.2 \text { years (mean) } \\
\text { standard deviation: } 6.2\end{array}$ \\
\hline Men & 101 \\
\hline Age of men & $\begin{array}{c}67.3 \text { years (mean) } \\
\text { standard deviation: } 5.8\end{array}$ \\
\hline Women & 203 \\
\hline Age of women & $\begin{array}{c}74.6 \text { years (mean) } \\
\text { standard deviation: } 6.7\end{array}$ \\
\hline
\end{tabular}

Polymorbidity, polypharmacy in studied group

\begin{tabular}{|l|c|}
\hline Without any somatic condition & $\begin{array}{c}13 \text { patients } \\
(4.3 \%)\end{array}$ \\
\hline $\begin{array}{l}\text { With some somatic condition } \\
\text { (1 and more diagnosed dis- } \\
\text { eases })\end{array}$ & $\begin{array}{c}291 \text { patients } \\
(95.7 \%)\end{array}$ \\
\hline $\begin{array}{l}\text { Somatic polymorbidity } \\
(2 \text { and more diagnoses })\end{array}$ & $\begin{array}{c}201 \text { patients } \\
(66.1 \%)\end{array}$ \\
\hline Polypharmacy & $\begin{array}{c}156 \text { patients } \\
(51.3 \%)\end{array}$ \\
\hline $\begin{array}{l}\text { - more medication than } \\
\text { needed, after review } \\
\text { of medication }\end{array}$ & $\begin{array}{c}46 \text { patients } \\
(15.1 \%)\end{array}$ \\
\hline $\begin{array}{l}\text { unsuitable combination } \\
\text { of drugs }\end{array}$ &
\end{tabular}

\section{Internal polymorbidity in studied group}

\begin{tabular}{|l|c|}
\hline Arterial hypertension & 182 patients $(59.9 \%)$ \\
\hline Hyperlipidemia of any type & 121 patients $(39.8 \%)$ \\
\hline $\begin{array}{l}\text { Angina pectoris, } \\
\text { ischemic coronary disease }\end{array}$ & 56 patients $(18.4 \%)$ \\
\hline $\begin{array}{l}\text { Flebotrombosis, } \\
\text { deep venous thrombosis }\end{array}$ & 13 patients $(4.3 \%)$ \\
\hline $\begin{array}{l}\text { Pulmonary emboli as a } \\
\text { complication during hospi- } \\
\text { talization }\end{array}$ & 88 patients $(28.9 \%)$ \\
\hline $\begin{array}{l}\text { Diabetes mellitus, } \\
\text { well compensated }\end{array}$ & 13 patients $(4.3 \%)$ \\
\hline Decompensated & 72 patients $(12.2 \%)$ \\
\hline $\begin{array}{l}\text { Other endocrinological con- } \\
\text { ditions (hypothyreosis etc) }\end{array}$ & $(13.8 \%)$ \\
\hline Rheumatologic conditions
\end{tabular}




\begin{tabular}{|l|c|}
\hline \multicolumn{2}{|c|}{ Neurological conditions in studied group } \\
\hline $\begin{array}{l}\text { Cervicalgia, thoracalgia, } \\
\text { lumbalgia or sacralgia }\end{array}$ & 98 patients $(32.2 \%)$ \\
\hline Stroke during hospitalization & 3 patients $(0.9 \%)$ \\
\hline
\end{tabular}

\begin{tabular}{|l|c|}
\hline \multicolumn{2}{|c|}{ Surgical conditions in studied group } \\
\hline $\begin{array}{l}\text { Falls during hospitaliza- } \\
\text { tion }\end{array}$ & 22 patients $(7.2 \%)$ \\
\hline $\begin{array}{l}\text { Brain commotion as a } \\
\text { result of falls }\end{array}$ & 1 patient $(0.3 \%)$ \\
\hline $\begin{array}{l}\text { Fractures as a result of } \\
\text { falls }\end{array}$ & 2 patients $(0.6 \%)$ \\
\hline $\begin{array}{l}\text { Acute abdominal states } \\
\text { - ileous states during } \\
\text { hospitalization }\end{array}$ & 6 patients $(1.9 \%)$ \\
\hline $\begin{array}{l}\text { Acute cholecystitis during } \\
\text { hospitalization }\end{array}$ & 3 patients $(0.9 \%)$ \\
\hline $\begin{array}{l}\text { Acute pancreatitis during } \\
\text { hospitalization }\end{array}$ & 2 patients $(0.6 \%)$ \\
\hline $\begin{array}{l}\text { Wounds as a result of falls } \\
\text { during hospitalization }\end{array}$ & 8 patients $(2.6 \%)$ \\
\hline
\end{tabular}

\begin{tabular}{|l|c|}
\hline \multicolumn{2}{|c|}{ Gynecological conditions in studied group } \\
\hline Metrorhagia & in 7 patients (2.3\%) \\
\hline $\begin{array}{l}\text { Breast pathological condi- } \\
\text { tions - diagnosed as a re- } \\
\text { sult of the presented study }\end{array}$ & 9 patients $(2.9 \%)$ \\
\hline
\end{tabular}

\begin{tabular}{|c|c|}
\hline $\begin{array}{c}\text { Dermatological conditions in studied group } \\
\text { of any type }\end{array}$ \\
\hline 22 patients & $(7.2 \%)$ \\
\hline \multicolumn{2}{|c|}{$\begin{array}{c}\text { Visual or hearing disturbances } \\
\text { in studied group }\end{array}$} \\
\hline 124 patients & $(40.8 \%)$ \\
\hline
\end{tabular}

\begin{tabular}{|l|l|}
\hline \multicolumn{2}{|c|}{ Infectious conditions in studied group } \\
\hline \multicolumn{2}{|c|}{ First diagnosed: } \\
\hline Hepatitis type A & 3 patients $(0.9 \%)$ \\
\hline Hepatitis B & 5 patients (1.6\%) \\
\hline Hepatitis C & none $(0.0 \%)$ \\
\hline Tuberculosis & 9 patients $(2.9 \%)$ \\
\hline
\end{tabular}

\begin{tabular}{|c|c|}
\hline \multicolumn{2}{|c|}{ Oncological surveillance } \\
\hline suspecting tumor & 16 patients $(5.3 \%)$ \\
\hline $\begin{array}{c}\text { Life threatening conditions } \\
\text { with cardiopulmonary resuscitation }\end{array}$ \\
\hline \multicolumn{2}{|c|}{12 patients (3.9\%) } \\
\hline
\end{tabular}

\section{CONCLUSION}

Gerontopsychiatrists and nurses working in gerontopsychiatry are sometimes disregarded as low-status health care professionals. In the Czech Republic gerontopsychiatry is still a specialization with very low attraction. The situation concerning the reputation of gerontopsychiatry can be different in other parts of the world. Our research is a small contribution to gerontopsychiatry showing that there is no reason to discriminate gerontopsychiatry as a subordinated medical specialization. Both doctors and nurses taking care of senior patients with psychiatric morbidity have to be skillful and have a comprehensive knowledge of all parts of medicine.

In our study, polymorbidity of senior patients hospitalized in gerontopsychiatric wards with psychiatric diagnosis was common. Polypharmacy was detected in our study in $51.3 \%$ of patients incoming for hospitalization and requiring corrections in therapy (taking into account the risks of side effects of used drugs and expenditures of the treatment).

The most frequent conditions in hospitalized senior citizens with gerontopsychiatric morbidity were: arterial hypertension, hyperlipidemia, dorsalgia, visual and hearing disturbances, diabetes mellitus.

Gerontopsychiatrists in the Psychiatric hospital in Kromeriz helped to indentify some oncological conditions in early stages in $5.3 \%$ of the cases, this fact underlines the importance of oncological screening and oncological surveillance.

\section{REFERENCES}

1. Cohen GD. African American Issues in geriatric psychiatry: a perspective on research opportunities. J Geriatr Psychiatry Neurol 1993; 6(4):195-9.

2. Engedal $\mathrm{K}$ et al. Psychiatry for the elderly - a speciality field in progress. Tidsskr Nor Laegeforen 1991;111(18):2258-60.

3. Le Clair JK, Sadavoy J. Geriatric Psychiatry Subspecialisation in Canada: past, present and future. Can J Psychiatry 1998; 43(7):681-7.

4. Ivanova K, Spirudova L, Kutnohorska J. Multikulturní ošetřovatelství. [Multicultural Nursing]. (In Czech). Grada. ISBN 80-247-1212-1. Praha 2005.

5. Luzny J. Kvalita života seniorů jako jedna z výzev zdravotně sociální politiky 21.století. Diplomová práce. [Quality of life in seniors as a challenge for health and social policy of 21 st century. Thesis]. (In Czech). Olomouc 2009.

6. Nieuwenhuijzen K, Mulder WJ, Pijpers E. Ageing and polymorbidity: is there a mismatch between the training of internists and the need? Neth J Med 2007; 65(10):363-5.

7. Topinkova E. Geriatrie pro praxi. [Geriatry for Practice] . (In Czech). Galen. ISBN 80-7262-365-6. Praha 2005. 
8. Ivanova K, Klos R. Kapitoly z lékařské etiky. [Chapters from Medical Ethics]. (In Czech). ISBN 80-244-0892-9, Olomouc 2004.

9. Lincova D, Farghali H. Základní a aplikovaná farmakologie. [Basic and applied pharmacology] . (In Czech). Galen, Universita Karlova. ISBN 80-7262-168-8. Praha 2002.

10. Kalvach Z, Onderková A. Stáří. Pojetí geriatrického pacienta a jeho problémů v ošetřovatelské praxi. [Ageing. Concept of geriatric patient and his problems in nursing practice]. (In Czech). Galen. Praha 2006.

11. Sein AJ, Chodorowski Z. Some aspects of pharmacotherapy among the eldest living in veterans' homes. Przegl Lek. 2002; 59(4-5):256-8.

12. Zlámal J, Ulrich M. Základy ekonomie pro management zdravotnictví. [Basic Economy for Management of Health Care]. (In Czech). ISBN 978-80-244-1992-3. Olomouc 2008. 